\title{
Primary de novo malignant giant cell tumor of kidney: a case report Rani Kanthan* and Bahman Torkian
}

\author{
Address: Department of Pathology, Room 2868, G Wing, Royal University Hospital, Saskatoon, Saskatchewan, S7N OW8, Canada \\ Email: Rani Kanthan* - inarkanth@shaw.ca; Bahman Torkian - torkian@yahoo.com \\ * Corresponding author
}

Published: 18 June 2004

BMC Urology 2004, 4:7 doi:10.1 I86/147/-2490-4-7

This article is available from: http://www.biomedcentral.com/I47I-2490/4/7

(C) 2004 Kanthan and Torkian; licensee BioMed Central Ltd. This is an Open Access article: verbatim copying and redistribution of this article are permitted in all media for any purpose, provided this notice is preserved along with the article's original URL.
Received: 10 December 2003

Accepted: 18 June 2004

\begin{abstract}
Background: Osteoclast-like giant cell tumors are usually observed in osseous tissue or as tumors of tendon sheath, characterized by the presence of multinucleated giant cells and mononuclear stromal cells. It has been reported in various extraosseous sites including breast, skin, soft tissue, salivary glands, lung, pancreas, female genital tract, thyroid, larynx and heart. However, extraosseus occurrence of such giant cell tumors in the kidney is extremely rare and is usually found in combination with a conventional malignancy. De-novo primary malignant giant cell tumors of the kidney are unusual lesions and to our knowledge this is the second such case.

Case Presentation: We report a rare case of extraosseous primary denovo malignant giant cell tumor of the renal parenchyma in a 39-year-old Caucasian female to determine the histogenesis of this neoplasm with a detailed literature review.

Conclusion: Primary denovo malignant giant cell tumor of the kidney is extremely rare. The cellular origin of this tumor is favored to be a pluripotential mesenchymal stromal cell of the mononuclear/phagocytic cellular lineage. Awareness of this neoplasm is important in the pathological interpretation of unusual findings at either fine needle aspiration or frozen section of solid renal masses.
\end{abstract}

\section{Background}

Osteoclast-like giant cell tumors are primarily observed in osseous tissue or as tumors of tendon sheath. As the name implies, this tumor is characterized by the presence of multinucleated giant cells and mononuclear stromal cells. In spite of mitotic activity in the tumor, diagnosis of malignancy is reserved for those cases with bizarre mitoses and cellular atypia or an association with malignant stromal sarcoma [1]. Although metastasis of the tumor is not commonly observed, tumor thrombi occur in up to $5 \%$ of the tumors [2]. Occurrences of tumors with osteoclast-like giant cells, have been reported in various extraosseous sites including breast, skin, soft tissue, salivary glands, lung, pancreas, female genital tract, thyroid, larynx and heart [3-12].
Extraosseus occurrence of osteoclast-like giant cell tumors in the kidney is extremely rare. Such tumors are usually found in combination with a conventional malignancy. De-novo primary malignant giant cell tumors of the kidney are unusual lesions and to our knowledge this is the second such case. A review of all the cases of giant cell lesions of the kidney published in the English literature is represented in chronological order in Table 1.

\section{Case presentation}

In March 2003, a 39-year-old Caucasian female was admitted to the Royal University hospital, Saskatoon, with a large right renal mass. Further investigations showed the presence of a tumor in the right kidney extending into the renal vein and up the vena cava. She 
Table I: Review of published cases of giant cell lesions of the kidney and renal pelvis

\begin{tabular}{|c|c|c|c|c|c|c|c|}
\hline Age & Sex & Location & Immunoreactivity & Associated Malignancy & Outcome & Author \& Reference & Year \\
\hline 56 & M & Renal Parenchyma & $\begin{array}{l}\text { Vimentin+, CD68+, } \\
\text { Cytokeratin-ve, CAM } \\
\text { 5.2-ve, AEI/AE3-ve }\end{array}$ & $\begin{array}{l}\text { Malignant fibrous histiocytoma } \\
\text { (MFH) }\end{array}$ & $\begin{array}{l}\text { Disease free at I } \\
\text { year }\end{array}$ & Chen C.H et al. [22] & 2003 \\
\hline 55 & $\mathrm{~F}$ & Renal Parenchyma & CD68+ & $\begin{array}{l}\text { Associated sarcomatoid } \\
\text { spindle cells with osteoid } \\
\text { production (osteosarcoma) }\end{array}$ & $\begin{array}{l}\text { Disease free at } 6 \\
\text { months }\end{array}$ & Lee, C.H et al. [19] & 2003 \\
\hline 30 & M & Renal Parenchyma & $\begin{array}{l}\text { Keratin \& EMA -ve, } \\
\text { Focally vimentin+ }\end{array}$ & $\begin{array}{l}\text { Clear cell type RCC, } \\
\text { sarcomatoid }\end{array}$ & $\begin{array}{l}\text { Disease free at } \\
14 \text { months }\end{array}$ & Koga, F. et al [20] & 2000 \\
\hline 81 & $M$ & Renal Parenchyma & $\begin{array}{l}\text { CD68++ Scattered } \\
\text { cytokeratin+, SI00+ }\end{array}$ & No & $\begin{array}{l}\text { Died } 2 \text { months } \\
\text { later }\end{array}$ & Heller, K.N et al. [2] & 1998 \\
\hline 55 & $\mathrm{~F}$ & Renal Parenchyma & $\begin{array}{l}\text { CD68+, CAM2.5+, } \\
\text { AEI/3+, EMA+, } \\
\text { Vimentin+ (Keratin } \\
\text { positive) }\end{array}$ & $\begin{array}{l}\text { No associated sarcomatoid } \\
\text { component }\end{array}$ & $\begin{array}{l}\text { Disease free at } 9 \\
\text { months }\end{array}$ & Chetty R, Cvijan D [14] & 1997 \\
\hline 69 & $M$ & Renal pelvis & $\begin{array}{l}\text { SI00+, CD68+, } \\
\text { EMA+; Vimentin+ }\end{array}$ & Papillary TCC & $\begin{array}{l}\text { Liver and lung } \\
\text { metastasis in } 5 \\
\text { months }\end{array}$ & Molinie, V. [17] & 1997 \\
\hline 75 & $\mathrm{~F}$ & Renal Parenchyma & CD68+ & $\begin{array}{l}\text { Clear cell type RCC and } \\
\text { sarcomatoid }\end{array}$ & $\mathrm{N} / \mathrm{A}$ & el-Naggar, A.K et al. [15] & 1993 \\
\hline 64 & M & Renal pelvis & $\mathrm{N} / \mathrm{A}$ & In-situ TCC & N/A & Borg-Grech, A. et al. [13] & 1987 \\
\hline 56 & $M$ & Renal pelvis & N/A & Papillary TCC & $\begin{array}{l}\text { Disease free at } \\
\text { one month }\end{array}$ & Kenney, R.M et al. [16] & 1984 \\
\hline 60 & $M$ & Renal pelvis & $\mathrm{N} / \mathrm{A}$ & No & $\begin{array}{l}\text { Disease free at I } \\
\text { year }\end{array}$ & Kimura, $\mathrm{K}$ et al. [2I] & 1983 \\
\hline 77 & $\mathrm{~F}$ & Renal pelvis & $N / A$ & SCC of the renal pelvis & $\mathrm{N} / \mathrm{A}$ & Hou, L.T \& Willis, R.A [I8] & 1963 \\
\hline 79 & $\mathrm{~F}$ & Renal Parenchyma & $\mathrm{N} / \mathrm{A}$ & $\begin{array}{l}\text { Tubular and papillary } \\
\text { adenocarcinoma }\end{array}$ & $\mathrm{N} / \mathrm{A}$ & Hou, L.T \& Willis, R.A [18] & 1963 \\
\hline
\end{tabular}

$\mathrm{TCC}=$ Transitional cell carcinoma SCC $=$ Squamous call carcinoma $\mathrm{M}=$ Male $\mathrm{F}=$ Female

underwent a radical right nephro-ureterectomy and partial excision of the vena cava wall was performed as a result of tumor adhesions to the vein. The immediate postoperative course was uneventful and the patient was discharged.

Pathological findings of the resected tissues are as follows:

\section{Macroscopic}

The gross specimen consisted of a right nephro-ureterectomy, adrenalectomy and fragments of the vena caval tumor thrombus. There was a pale tan tumor mass that measured $7.5 \times 7 \times 6 \mathrm{~cm}$ within the upper pole of the kidney. There was mild dilatation of the pelvicalyceal system towards the upper pole with extension of the tumor onto the mucosal surface of the pelvis. Full-faced slices of the tumor showed the tumor to extend close to the inked margins of the perinephric fat. (Figure 1)

\section{Microscopic}

Light microscopic examination with routine hematoxylin and eosin stained slides showed the presence of ovoid plump shaped mononuclear cells interspersed with multinucleated giant cells in a vascularized stroma. Both the

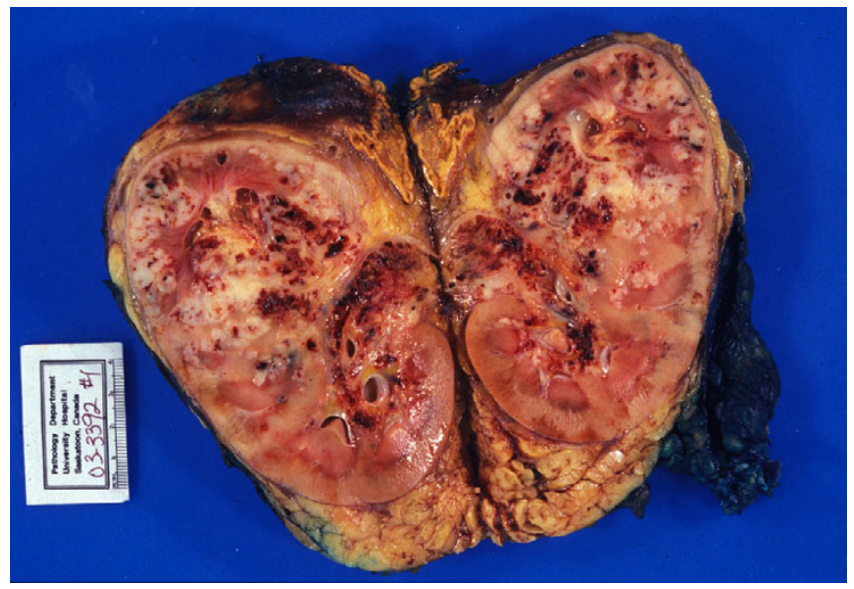

Figure I

Gross photograph of the sliced kidney demonstrates the large renal mass occupying the upper pole of the kidney. 


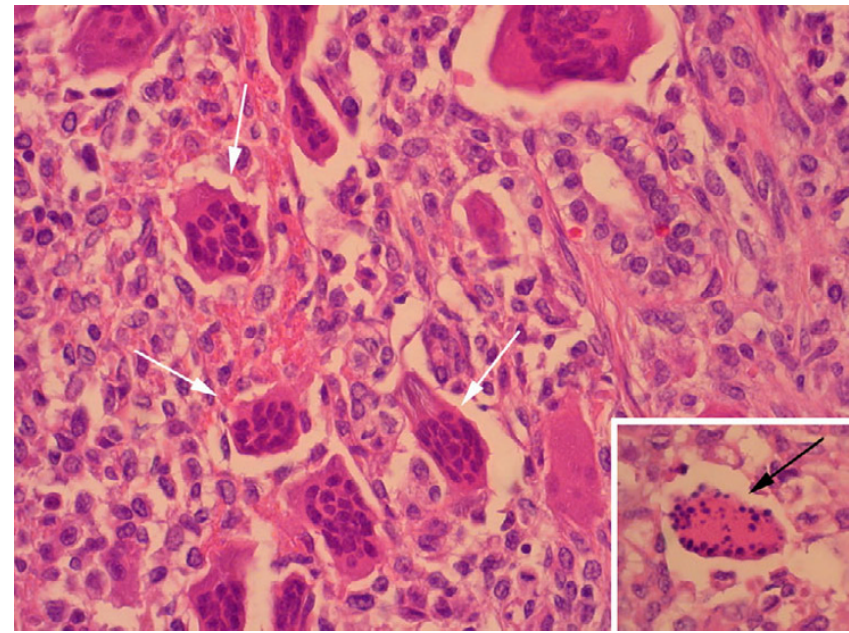

\section{Figure 2}

Haematoxylin and eosin stained slides shows the stromal and multinucleated giant cell components of this neoplasm. The inset figure shows an apoptotic giant cell.

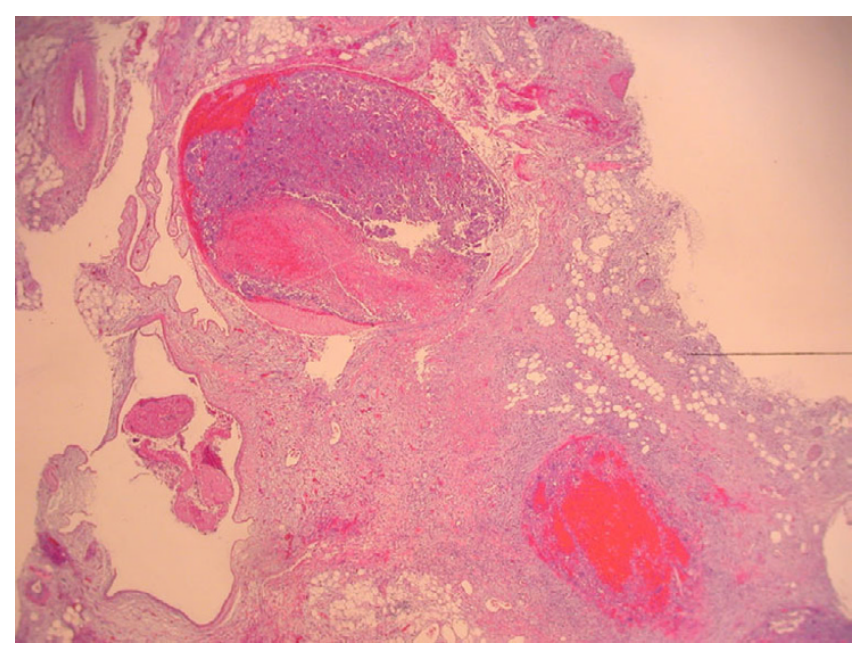

Figure 3

Angiolymphatic invasion with nodules of tumor in the perinephic fat.

stromal and the multinucleated giant cells appeared morphologically to be highly reminiscent of giant cell tumor lesions of bone (Figure 2). The stromal cells consisted of mononuclear round to spindle shaped cells with evidence of mitotic activity and mild cellular atypia. The giant cells had multiple nuclei, often numbering 25 to 40 , many of which were ovoid with occasional nucleoli. Mitosis and pleomorphism in the giant cells was not easily observed

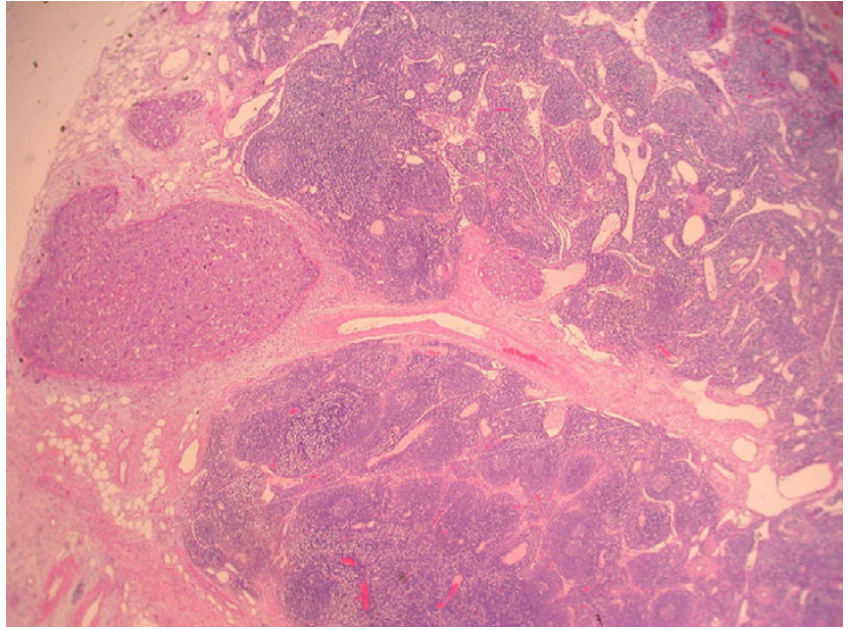

\section{Figure 4}

Hilar lymph node metastasis.

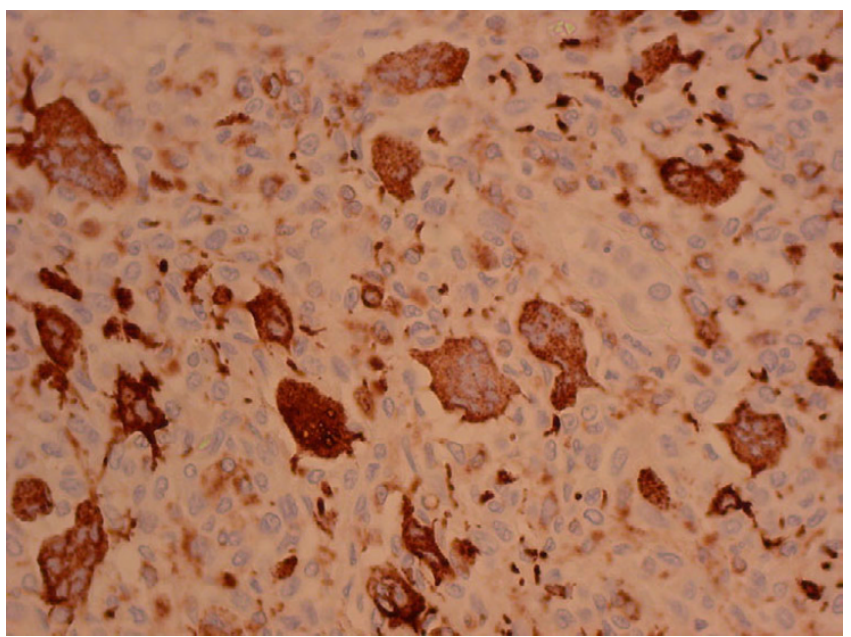

\section{Figure 5}

Staining with CD68 antibodies was strongly positive in the multinucleated giant cells.

though apoptotic giant cells were easily observed (Figure 2-inset). Detailed examination with multiple sections revealed no evidence of any associated papillary or sarcomatoid or typical renal cell carcinoma. The tumor infiltrated widely through the hilar region into the pelvis of the kidney and extended as nodules into the adjacent cortex abutting onto the renal capsule and was also present in the adjacent perirenal fat (Figure 3 ) However, the tumor 


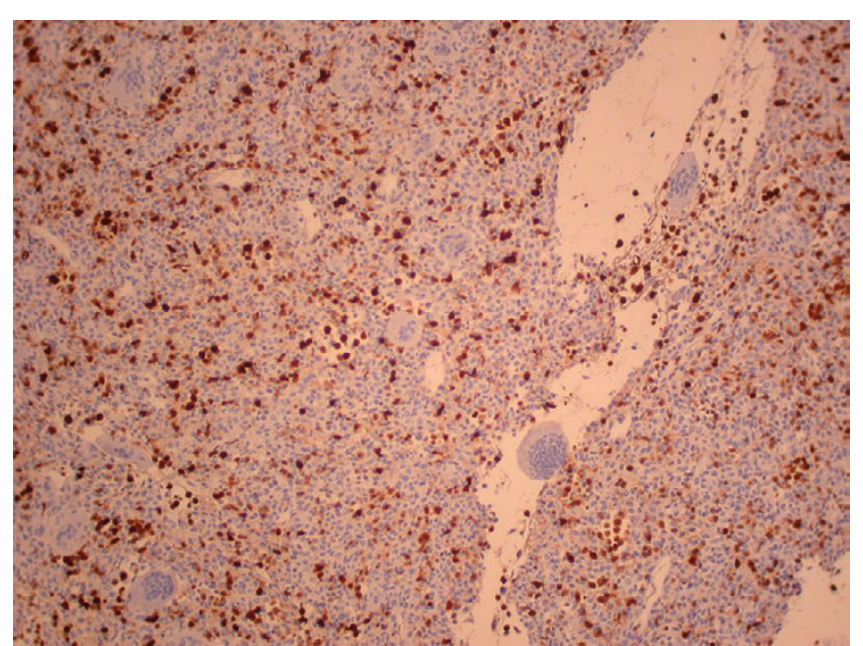

Figure 6

Antibodies to Mac387 highlighted the majority of the stromal mononuclear cell component.

was limited externally by the Gerota's fascia. Multiple sections of the hilar region showed the presence of tumor metastasis within the hilar lymph nodes (Figure 4) Invasion of the tumor was also observed in the renal vein, vena cava, perirenal fat, lymphatic and perineural space. Invasion to the vena cava presented as a tumor thrombus. Large areas of necrosis and hemorrhage were also seen within the neoplastic lesion. Neither osteoid nor cartilaginous differentiation were demonstrated. Sections of the non-neoplastic areas of the kidney showed mild interstitial lymphocytic infiltrate as a peritumoral response.

\section{Immunohistochemical}

Various immuno-histochemical markers were performed with appropriate positive and negative controls. Negative controls were achieved by omission of the primary antibody. The lesional cells showed no expression with low and high molecular weight keratin, pan-cytokeratin there was no expression of CK7, CK20, CK17, P53, BCL2, CD45 and HMB45 either. Anti body staining for S-100 was faintly expressed in some of the lesional cells. However, staining with CD68 antibodies was strongly positive in the multinucleated giant cells (Figure 5). Majority of the stromal mononuclear cell component was highlighted with antibodies to MAC387 (Figure 6). Vimentin also highlighted the same and occasional giant cells. Staining with Ki67 antibodies was over expressed in the lesional cells in keeping with the high proliferative and apoptotic nature of the lesion.

\section{Ultrastructural}

The electron microscopic study was performed on tissue samples obtained from the formalin fixed specimen. Both multinucleated giant cells and the stromal cells were examined in detail. Examination of the giant cells showed the cytoplasm to be filled with numerous vesicles and vacuoles many of which were consistent with primary or secondary lysosomes (Figure 7). Many of the secondary lysosomes typically exhibited a heterogeneous content with some prominent lipid accumulation. Scattered mitochondria and rough endoplasmic reticulum were also identified within these cells. They also contained multiple nuclei of various contours and irregular shapes with occasional one or two prominent nucleoli. Small foot-like projections and cell processes were observed on the surface of these multinucleated giant cells. These projections/processes did not qualify as true microvilli as they lacked the filamentous core rootlet and did not possess any evidence of secretory granules at the base of these pseudorootlets (Figure 8). Examination of the stromal cells showed abundant rough endoplasmic reticulum with dilated cisternae and mitochondria. Simple cell matrix junctions were observed but no true desmosomes were identified (Figure $9)$. There was no evidence of an external lamina, focal densities, microfilaments, tonofibrils or tonofilaments. Some cells showed the presence of intracytoplasmic accumulation of unusual filaments many of which were in a well-defined curving and somewhat rolled appearance in keeping with vimentin type of intermediate filaments (Figure 10). The extracellular matrix and stroma consisted mainly of filamentous collagen fibres with its distinctive cross-striated pattern.

\section{Discussion}

Neoplasms associated with osteoclast-like giant cells have been reported in various extraosseous epithelial sites [312]. Frequently, these neoplasms have been associated with a conventional carcinomatous element. In the kidney this is a rare tumor and majority of the cases reported seem to occur in association with papillary, transitional, clear cell type of renal cell carcinoma or sarcomatoid carcinoma or osteosarcomatous transformation [1320]. Kimura et al reported the occurrence of a multinucleated giant cell tumor of the renal pelvis that was considered to be primary, de-novo and benign [21]. Heller et al. [2] were the first to report malignant osteoclast-like giant cell tumor of the kidney without an association with a carcinoma or sarcoma. This case report is the second in this series of de-novo primary malignant giant cell tumor of the kidney not associated with any other conventional renal neoplasm.

The diagnosis of primary malignancy in a giant cell tumor of bone is reserved for those lesions that display bizarre mitoses and cytological atypia or secondary malignancy 


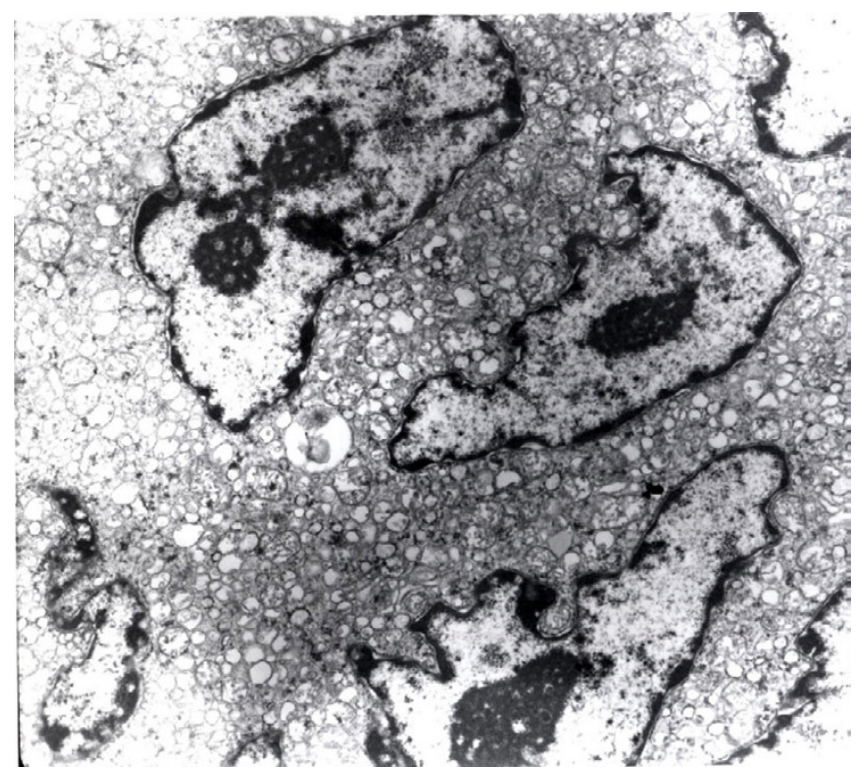

Figure 7

Malignant multi-nucleated cell studded with primary and secondary lysosomes. (magnification $\times 12,0000$ )

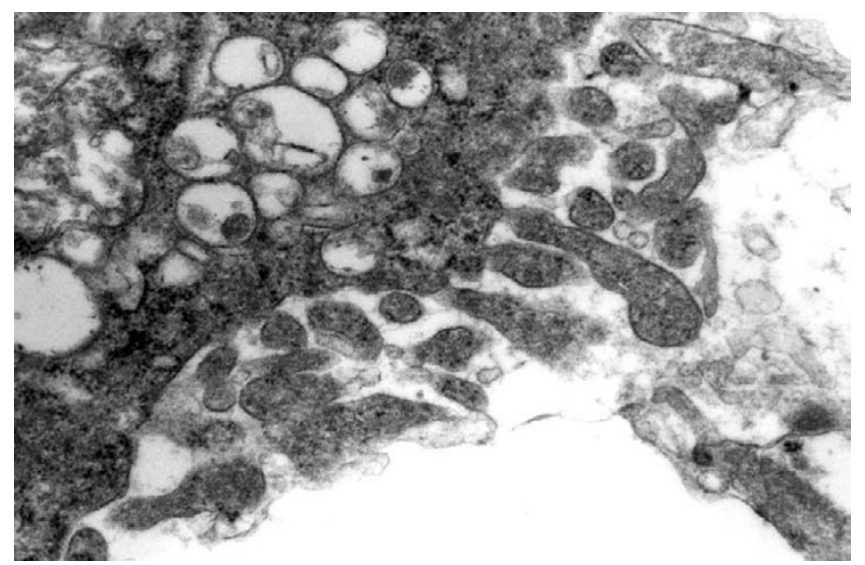

Figure 8

Pseudomicrovilli at the cell surface. (magnification $\times 24,000$ )

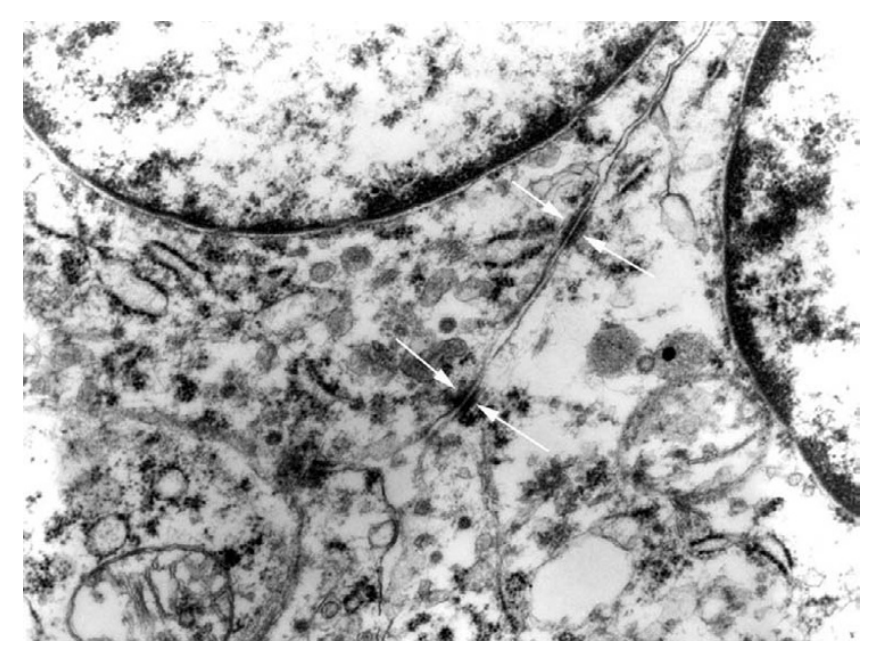

Figure 9

Simple cell junctions (magnification $\times 38,400$ )

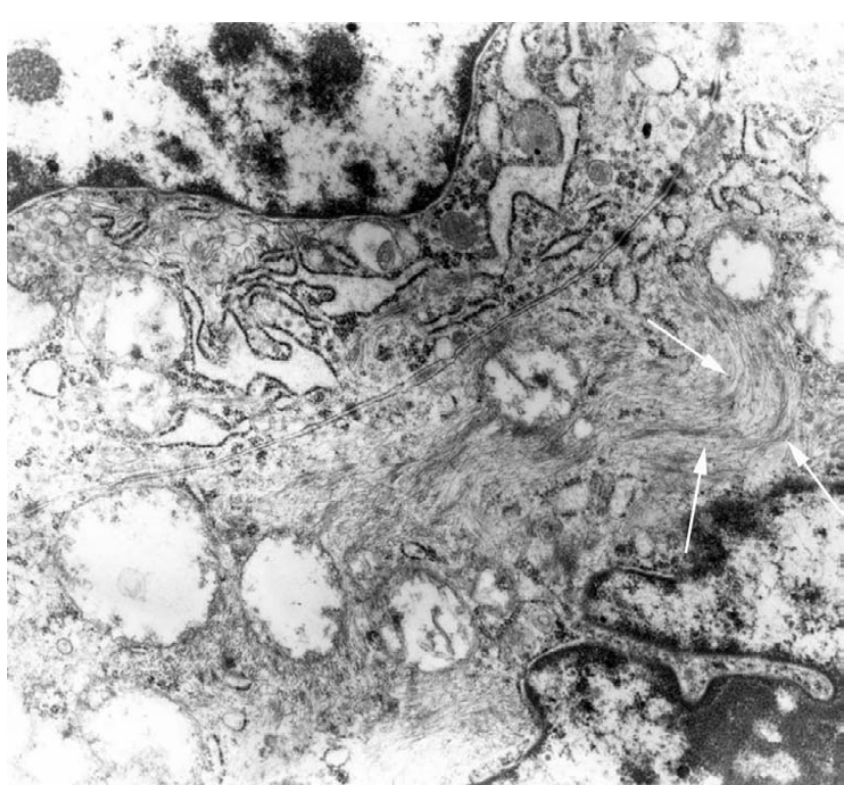

Figure 10

Intracytoplasmic collection of whorled filaments of vimentin (magnification $\times 30,000$ )

The cell of origin of this tumor is believed to be from the mesenchymal cell of mononuclear phagocyte cell line $[2,19,21]$, although others $[13,14,17,20]$ suggested an epithelial origin. Some authors also felt that these giant cells were non-neoplastic and represented a stromal response to the conventional carcinomatous element $[15,16,18]$. The multinucleated giant cells of the present of a sarcomatous growth in previously documented benign giant cell tumor of bone [1]. Our case was diagnosed as malignant as it exhibited features such as widespread areas of necrosis and hemorrhage; perineural, vascular and angiolymphatic invasion; vena caval tumor thrombus and the presence of tumor metastasis within adjacent hilar lymph nodes. 
case showed strongly positive immunoreactivity with CD68, confirming its monohistiocytic origin. CD68 is widely used to identify cells of monohistiocytic origin. The CD68 antigen is a 110 kilo Dalton highly glycosylated transmembrane protein which is mainly located in the lysosomes. The antibody stains macrophages in many human tissues. In addition, the antibody reacts with plasmacytoid T-cells that are present in many reactive lymph nodes, and these are also believed to be of monocyte/macrophage origin. However Chetty et al. [14] noted that a positive reaction to $\mathrm{CD} 68$, a lysosomal marker, can be positive in tumors of diverse histogenesis with a granular cytoplasm and can be misleading. The strongly positive staining of the CD68 exclusively in the giant cells of the present case indicates a monocytic/histiocytic origin of these cells. The co-expression of MAC387, lysozyme, faint expression of S-100 and a strong immunohistochemical expression of vimentin of the stromal cells favors a mesenchymal/histiocytic/monocytic origin of the tumor cells. There was no supporting evidence for an epithelial origin for this lesion despite the use of an extensive immunohistochemical epithelial marker panel.

Ultra structural analysis in the present case also supported a non-epithelial origin of the tumor by the presence of rough endoplasmic reticulum with dilated cisterna and mitochondria, absence of true desmosomes, the most important organelle in the ultrastructural definition of epithelium and also no evidence of external lamina tonofibrils or tonofilaments. These findings are also supported in Kimura's case report of giant cell tumor of the kidney [21].

\section{Conclusions}

Primary denovo malignant giant cell tumor of the kidney is extremely rare. The cellular origin of this tumor is favored to be a pluripotential mesenchymal stromal cell of the mononuclear /phagocytic cellular lineage. Awareness of this neoplasm is important in the pathological interpretation of unusual findings at either fine needle aspiration or frozen section of solid renal masses.

\section{Competing interests}

None declared.

\section{Authors' contributions}

RK is the surgical pathologist who diagnosed and followed up the case and BT participated actively in the production of this manuscript.

\section{Acknowledgements}

"Written consent was obtained from the patient or their relative for publication of study"
The authors also would like to thank Mr. Todd Reichert, Michelle Hesson and Karen Slattery for their expert technical assistance in the production of the illustrations.

\section{References}

I. Meis JM, Dorfman HD, Nathanson SD, Haggar AM, Wu KK: Primary malignant giant cell tumor of bone: "dedifferentiated" giant cell tumor. Mod Pathol 1989, 2:54I-546.

2. Heller KN, Manyak MJ, Tabbara SO, Kerr LA: Malignant osteoclast-like giant cell tumor of the kidney. Urology 1998, $5 \mathrm{I}: 495-498$.

3. Fukunaga M: Giant cell tumor of the breast. Virchows Arch 2002, 44I:93-95.

4. Hoang MP, Rogers BB, Albores-Saavedra J: Giant cell tumor of the skin: a morphologic and immunohistochemical study of five cases. Ann Diagn Pathol 2002, 6:288-293.

5. Holst VA, Elenitsas R: Primary giant cell tumor of soft tissue. J Cutan Pathol 200I, 28:492-495.

6. Itoh $Y$, Taniguti $Y$, Arai $K$ : A case of giant cell tumor of the parotid gland. Ann Plast Surg 1992, 28:183-186.

7. Orosz Z, Toth E, Viski A: Osteoclastoma-like Giant Cell Tumor of the Lung. Pathol Oncol Res 1996, 2:84-88.

8. Shiozawa M, Imada T, Ishiwa N, Rino Y, Hasuo K, Takanashi Y, Nakatani $Y$, Inayama $Y$ : Osteoclast-like giant cell tumor of the pancreas. Int J Clin Oncol 2002, 7:376-380.

9. Sieinski W: Malignant giant cell tumor associated with leiomyosarcoma of the uterus. Cancer 1990, 65:1838-1842.

10. Silverberg SG, DeGiorgi LS: Osteoclastoma-like giant cell tumor of the thyroid. Report of a case with prolonged survival following partial excision and radiotherapy. Cancer 1973, 31:621-625.

II. Wieneke JA, Gannon FH, Heffner DK, Thompson LD: Giant cell tumor of the larynx: a clinicopathologic series of eight cases and a review of the literature. Mod Pathol 200I, 14:I209-1215.

12. Acharyya B, Deb HK: Osteoclastoma at unusual site. J Indian Med Assoc 1990, 88:259-260.

13. Borg-Grech A, Morris JA, Eyden BP: Malignant osteoclastomalike giant cell tumour of the renal pelvis. Histopathology 1987, I I:415-425.

14. Chetty R, Cvijan D: Giant (bizarre) cell variant of renal carcinoma. Histopathology 1997, 30:585-587.

15. el-Naggar AK, Gaber K, Ordonez NG: Renal cell carcinoma with osteoclast-like giant cells. Virchows Arch A Pathol Anat Histopathol 1993, 422:427-431.

16. Kenney RM, Prat J, Tabernero M: Giant-cell tumor-like proliferation associated with a papillary transitional cell carcinoma of the renal pelvis. Am J Surg Pathol 1984, 8:139-144.

17. Molinie V, Pouchot J, Vinceneux P, Barge J: Osteoclastoma-like giant cell tumor of the renal pelvis associated with papillary transitional cell carcinoma. Arch Pathol Lab Med 1997, 121:162-166.

18. Hou LT, Willis RA: Renal carcino-sarcoma, true and false. J Pathol Bacteriol 1963, 85: I39-I 44.

19. Lee CH, Lee SD, Lee JW, Kim JY, Park do Y, Sol MY, Suh KS: Malignant osteoclast-like giant cell tumor of the kidney with osteosarcomatous transformation. J Urol 2003, 169:272-273.

20. Koga F, Kawano K, Honda M, Sumi S, Horimi H, Kondo S, Yoshida K: Sarcomatoid renal cell carcinoma with scant carcinomatous components. Int J Urol 2000, 7:58-60; discussion 6I.

21. Kimura K, Ohnishi Y, Morishita H, Amezaki M, Irikura H: Giant cell tumor of the kidney. Virchows Arch A Pathol Anat Histopathol 1983, 398:357-365.

22. Chen $\mathrm{CH}$, Lee PS, Han WJ, Shen KH: Primary giant cell malignant fibrous histiocytoma of the kidney with staghorn calculi. J Postgrad Med 2003, 49:246-248.

\section{Pre-publication history}

The pre-publication history for this paper can be accessed here:

http://www.biomedcentral.com/1471-2490/4/7/prepub 